\title{
“Çerçeve”nin Ötesi:
}

\section{Mültecinin Görsel İmgesinde Kaybın Yokluğu*}

\author{
N. Gamze Toksoy, Deniz Zeybek ve Berna Akdoğan*
}

\section{Öz}

İnsanların savaşlar, siyasal, ekonomik, sosyal vb. nedenlerle zorunlu yer değiştirmeleri veya göçü günümüzde kitleleri etkileyen bir soruna dönüşmüştür. Hem niceliği hem de etkilediği coğrafi alanın büyüklüğüne işaret edilerek çoğu zaman "mülteci krizi" olarak adlandırılan insan hareketliliği, beden politikalarını ve ayrımcı pratikleri yeniden tartışmaya açmayı gerekli kılmaktadır. Zira, yaşam alanlarını terk ederek tehlikeli yollardan daha güvenli algılanan ülkelere doğru hareket eden topluluklar, ağır insan hakları ihlallerine maruz bırakılmaktadırlar. Göç yolunda hayatta kalma mücadelesini başarsalar bile sonrasında, mülteci kimliğinin getirdiği zorluklarla karşı karşıya kalmaktadırlar. Mültecilerin çeşitli şekillerde maruz kaldıkları ötekileştirici tutum ve davranışların beslendiği ortamın yaratılmasında görsel imgelerin rolü vardır. Bu metinde ilkin, mültecinin bedeninin medyada yaygın dolaşıma giren görsel imgeleri ile beden politikaları arasındaki bağlar tartışmaya açılmaktadır. Belli bir çerçeve içinde tekrarlanan ve mültecileri toplumsal soruna indirgeyen algıyı kuvvetlendiren görsel imgeler, biopolitikaya dair kavramlar aracılığılla sorgulanmaktadır. Böylece, görsel imgelerdeki ortaklıkların bedenlere yönelik politikalarla ilişkisi makro perspektifle ve kavramsal olarak ele alınmaktadır.

Ardından metinde, göç edenlerin yaşadıkları şiddetin, kaybın görsel temsiline dair alternatif yaklaşımlar geliştirmenin önemine işaret edilmektedir. Günümüz medyasının aynılaşan temsil biçimleri eleştirilirken, karşı temsilin mümkünlüğü sorgulanmakta ve mevcut görsel rejimin belirlediği çerçevenin ötesinde düşünmenin, tartışmanın imkanları araştııımaktadır. İzleyiciye sunulan acılı yaşamlar olmanın ötesinde, kaybı yaşayanların kendi hikâyelerini aktarmanın yollarından birini açan Arpillera örneği bu bağlamda ele alınmakta ve görsel rejimin mutabakat alanının dönüştürülmesinin nasıl mümkün olabileceğine dair soruların uyarıcı örneği olarak değerlendirilmektedir.

Anahtar Sözcükler: Mülteci, biyo-politika, görsel imge, kayıp, Arpillera

\footnotetext{
* Geliş tarihi: 16/01/2020 • Kabul tarihi:14/03/2020

** N. Gamze Toksoy: Mimar Sinan Güzel Sanatlar Üniversitesi, Fen Edebiyat Fakültesi, Sosyoloji Bölümü. Orcid no: 0000-0002-7506-897, gamzetoksoy@gmail.com

Deniz Zeybek: Mimar Sinan Güzel Sanatlar Üniversitesi, Fen Edebiyat Fakültesi, Sosyoloji Bölümü. Orcid no: 0000-0003-2535-9573, denizzeybek8@gmail.com

Berna Akdoğan: Mimar Sinan Güzel Sanatlar Üniversitesi, Fen Edebiyat Fakültesi, Sosyoloji Bölümü. Orcid no: 0000-0002-8102-5079, bernaakdogann@gmail.com
} 


\title{
Beyond the "Frame"
}

\section{Absence of Loss in the Visual Image of Refugees*}

\author{
N. Gamze Toksoy, Deniz Zeybek and Berna Akdoğan ${ }^{\star *}$
}

\begin{abstract}
Forced displacement and migration caused by wars, political, as well as economic or social reasons have become a problem affecting a great number of people. This mobility which is oftentimes called "the refugee crisis" due to its quantity and the large geographical area it affects makes it necessary to discuss body politics and discriminatory practices. For, the masses of people, that have left the places they lived to reach developed countries through dangerous paths, have been facing serious human rights violations. Even when they survive the migration path, they will have to suffer the consequences of being a refugee. Visual images play an important role in creating the atmosphere that feeds the marginalization experienced by refugees in various contexts. This paper examines, first, the widespread images of the refugee body in the media alongside a discussion on body politics. These images, which are replicated within a specific framework, reduce refugee lives to a societal problem that needs to be solved. This framework will be discussed through notion of bio-politics. Thus, the relationship between the common elements in these images and the political attitudes towards these bodies will be conceptually examined from a macro-perspective. Later, this paper will deal with the importance of developing alternative ways of representing the violence and loss experienced by displaced people. It will discuss homogenous representation in media and consider the possibility of a counter-representation method that can be thought beyond the framework shaped by the current visual regime. Arpillera will be taken as an example of an instance when people who have experienced loss, have been able to convey their own stories and turn the visual regime into an area of reconciliation. Arpillera will be examined as an instance that can open doors to a specific mode of representation that goes beyond the painful lives narrative that is presented to audiences.
\end{abstract}

Keywords: Refugee, bio-politics, visual image, loss, Arpilleras

\footnotetext{
* Received: 16/01/2020 • Accepted:14/03/2020

${ }^{*}$ N. Gamze Toksoy: Mimar Sinan Fine Arts University Faculty of Ats and Sciences Department of Sociology. Orcid id: 0000-0002-7506-897, gamzetoksoy@gmail.com

Deniz Zeybek: Mimar Sinan Fine Arts University Faculty of Ats and Sciences Department of Sociology. Orcid id: 0000-0003-2535-9573, denizzeybek8@gmail.com

Berna Akdoğan: Mimar Sinan Fine Arts University Faculty of Ats and Sciences Department of

Sociology. Orcid id: 0000-0002-8102-5079, bernaakdogann@gmail.com
} 


\section{“Çerçeve”nin Ötesi: Mültecinin Görsel İmgesinde Kaybın}

\section{Yokluğu}

Günümüz medyasında yaygın dolaşımda olan ve tekrarlanan mültecilere dair görsel imgelerin niteliğini sorgulamak, mültecilerin yaşadıkları zorlukları, onlara yönelik dışlayıcı tutum ve davranışları, önyargıları anlamanın yollarından biridir. Nitekim, görsel imgeler günümüz iktidarlarının yaşamaya değer bedenlerle ötekiler arasında koyduğu sınırın belirginleştiği ve kanıksatıldığı araçlara dönüşmüşlerdir. Savaşların, yoksulluğun, göçün görsel temsili üzerinde denetim kurmak, hangi acıların, nasıl gösterileceğini belirlemek bedenlere yönelik ayrımcı politikaların devamıdır. Modern tekniklerle yeniden üretilebilen fotoğraf gibi görsel imgeler ilk dönemlerinden itibaren toplumları denetlemenin ve sınıflandırmanın aracı olmuşlardır ve fotoğraf tarihi bunun nasıl mümkün olduğunun çok sayıda örneğini barındırır (Toksoy, 2019: 491-505). Bu bağlamdaki tartışmaların temelini ören Susan Sontag (2004), başkalarının acısını sergileyen savaş fotoğraflarının modern iktidarlar açısından işlevlerini gösterir. Sontag bize, seyirlik bakışa sunulan başkalarının acısının, şiddet karşıtı toplumsal hareketleri beslemediği gibi tersine toplumsal yargıları ve normları güçlendirdiğine dair kapsamlı bir tartışma sunar. Dünyanın az gelişmiş olarak adlandırılan coğrafyalarında yaşanan ölümlere, şiddet olaylarına, savaşlara ait görüntüler sistematik olarak yaygınlaştırılır. Yaşananların, kaybın sınırlı bir bakıştan tanımlanmasına neden olan bu görüntüler, yoksulluğun, şiddetin olağan görülmesine, çaresizliğin yeniden üretilmesine yol açabilirler (2004: 7-12).

Benzer biçimde mültecileri konu edinen görsel imgeler, onları özneleşemeyen kitleler olarak sunar, düşkünleştirir ve pasif kurbanlara dönüştürür. Mevcut görsel rejimin, mültecinin bedenini ötekileştiren ve insanlıktan çıkaran imgeleri çeşitlidir. Bir taraftan botlarla, teknelerle yaklaşan tehlikeli kalabalıklar imgesi tekrarlanarak grup kimliği vurgulanır öte yandan kadın ve çocukların yakın plan yüzlerindeki çaresizlik gösterilerek güçsüz ve bizim yardımımıza muhtaç varlıklar yaratılır. Klişeleşmiş bu görsel imgeler ile mültecilik tanımı birbirine sıkı sıkıya bağlıdır. Böylece, bedenler anonimleştirilir, göçün insanlar üzerinde yarattığı etkiler fiziksel kayıplara indirgenir, kişisel deneyimler ve duygulanımlar görünmezleştirilir (Malkki, 1997; Chouliaraki ve Stolic, 2017). Yakın planda gösterilen ve izleyicide empati duygusu yaratması 
beklenen "ideal kurbanlar", yüzleri seçilebilen, çaresizce kameraya bakan kadınlar, çocuklar, yaşlılardır. Yüzleri seçilmeyen, çoğunluğu erkek, teknelerdeki kalabalıklar ise medyada mültecilere dair egemen görsel temsildir ve bu yolla mülteciler isimsiz kitlelere dönüştürülürler. Yaşam mücadeleleri nesneleştirilir, genelleştirilir ve ülkelerin sınır güvenliğini tehdit eden tehlikeli unsurlar olarak çerçevelenirler (Bleiker vd., 2013: 408-412).

Elinizdeki metinde, medya araştırmalarının ortaya koyduğu bu sözünü ettiğimiz mülteci bedenini tanımlayan görsel çerçeve, belli temalar etrafında ve görsel imgelerle modern iktidarların işleyişi arasında kavramsal bağlar kurmaya izin verecek bir yaklaşımla ele alınıyor. Medya incelemelerinin ortaya koyduğu görsel imgelerdeki tekrarların, ortaklıkların, bugün mültecilere dair sürdürülmekte olan beden politikalarını nasıl desteklediğini göstermeyi hedefliyor. Dünyanın farklı coğrafyalarında, farklı sosyal, politik, ekonomik koşullara rağmen mültecilere yönelik ötekileştirici algı güçlenmektedir. Medyada yabancı düşmanlığının neden olduğu şiddet olaylarına sıklıkla rastlanır ve bu tür düşmanlıkların beslenmesinde görsel imgelerin rolü ve etkisi artmaktadır. Nitekim, görselliğin alanında tanımlayıcı, damgalayıcı imgelemlerin belli bir grup aleyhinde yargı oluşturma gücü yüksektir. Ayrımcılık, kökeninde tanımlama olan bir dışlama mekanizmasıdır ve toplumların tektipleştirilmesine dayanır (Göregenli, 2013: 23). Ötekinin, sürekli olarak grup kimliğini yerleşikleştirecek şekilde tanımlanmasını mümkün kılan mekanizmaları mercek altına almak, toplumsal alanda dışlama formlarının nelerden beslendiğini, nasıl sistematikleştiğini görmemiz için elzemdir. Zira, ayrımcılığın yaygınlaşması ve sürdürülmesi, ayrımcı bakışın toplumun geniş kesimleri tarafından onaylanmasıyla ve onun toplumsal alanda meşrulaştırılmasıyla mümkün olur. Görsel imgeler, belli grupları belli çerçeveler içine sıkıştırarak, klişeler yaratarak onlara dair total bir algı oluşturarak bu meşrulaştırma araçlarından birine dönüşebilir, "yabancı" olarak tanımlanan kişilere ve gruplara yönelik yerleşik ayrımcı toplumsal normları güçlendirebilir. Bu nedenle metinde, yaygın dolaşımda olan imgelerdeki tekrarların toplumsal etkilerine işaret edilmektedir. Dolayısıyla bedenlerin belli bir algıyı güçlendirecek şekilde temsil edilmesini sorunsallaştıran bir tartışma örülmektedir.

Yaşamlarımızı tehdit eden tekinsiz kalabalıklar olarak temsil edilen mülteciler, imgesel tekrarda, büyüyen toplumsal soruna ve yardıma muhtaç kitlelere 
dönüştürüldükçe, onların bireysel kimlikleri, göçten önceki yaşamları görünmezleşir. Belki de hiç dönemeyecekleri ülkelerindeki kayıpları, geride bıraktıkları, evleri, eşyaları, sevdikleri, bugüne kadar biriktirdikleri öyküleri silinir. Yerine, kitlesel göçün göstergeleri kalır, bazen içine sığılamamış dev bir gemide, bazen can yelekleriyle botlarda, bazen çuvallarıyla yollarda yığınlar olurlar. Göçmenlerin medyada yaygın dolaşımda olan bu görsel temsilleri bize onların deneyimleri hakkında ne anlatır? Bellekten yoksun, bir yere ait olma duygusundan koparılmış imgelerle hayatta kalma çabası, yeniden var olma arzusu anlaşılabilir mi? Kayıp, görsel dilde nasıl temsil edilebilir? Görsel imgelerle, hatırlamanın, yüzleşmenin, kaybın ve yasın olanağı yaratılabilir mi?

Bu gibi soruları tartışmak, kaybı yaşayanların kayıplarını, yaslarını mevcut görsel rejimin belirlediği çerçevenin ötesinde aktarmanın imkanlarını araştırmak üzere, elinizdeki metnin son bölümünde Şilili kadınların yaptıkları yama işleri olarak bilinen Arpilleralara yer veriliyor. Bu bölümde, tekrarlanan temsil biçimlerinin çizdiği çerçevesinin ötesine, öznelerin kendi hikayelerini aktarabilecekleri alanlara dikkatleri yöneltmek hedefleniyor. Arpillera gibi örnekler üzerinden, elbette mevcut görsel rejimin bütünüyle dönüşmesini beklemek mümkün değildir. Ancak seyirci konumumuzu sorgulamanın, kendi kaybını aktarabilen öznelerin temsil sahnesini kurması için alanlar yaratmanın yolu biraz da bu alternatif çabaları canlı tutmaya, tartışıı hale getirmeye bağlıdır. Temsil sahnesini sorgulayan farklı biçimleri hatırlamak, kaybını kendi dilinden aktaramayanların, yasını duyuramayanların özne olma mücadeleleri için fikir açıcı yollardan biri olabilir.

\section{Beden Politikaları ve Mültecilik}

Mültecilere dair görselleştirmelerin günümüz medyasında yaygınlığını ve işlevini anlamak için, yaşam ve ölümün politikaya nasıl dahil edildiğini ve görünüm alanının nasıl düzenlendiğini hatıllamak gerekir. Zira, insan türünün biyolojik varlığının üstün olanlar ve altta konumlandırılanlar ön kabulüyle sınıflandırılması hala geçerlidir ve yaşamaya değer bulunan bedenleri ötekilerden ayrıştırmayı sağlayan modern devletin politikalarının temelini oluşturur. Bugün tekrarlanan mülteci bedeninin görsel temsilleri, bu ön kabullerin sürdürülmesine karşı argüman oluşturmazlar. Tersine, mülteciler, sınırlarla bölünmüş devletlerin kendi sınırları içinde yaşam hakkı tanıdıklarını, vatanın 
ası sahiplerini, yani yaşaması gereken bedenleri tehdit eden tekinsiz yabancılar olarak imgesel alanda yerleşikleşir. Görsel alanın düzenlenmesini sağlayan politikalar bu bağlamda, egemenin bir bütün olarak insanın biyolojik varlığına yönelik içeriye alma ve dışarıda bırakma pratikleriyle örtüşür. Dışarıda bırakılanlar, geri kalanların yaşamaya değer hayatları için vazgeçilenlerdir.

Michel Foucault (2003; 2008), modern iktidarın işleyişini sağlayan esasın, beden üzerindeki denetim mekanizmaları olduğunu göstermiştir. Modern iktidarı, geleneksel hükümranlıktan belirgin bir şekilde ayrıştıran, yaşatmaya odaklı nüfusun biyopolitikasıdır. Biyo-politika, en genel anlamıyla, doğum ve ölüm oranlarının, yaşam süresinin, sağlık düzeyinin, nüfus değişimlerinin, göç ve barınmanın belirli müdahalelerle düzenlenmesini yani insan bedeninin kontrolünü ve denetlenmesini ifade eder. Biyo-iktidar gücünü, siyasetin öznesi haline getirdiği insan yaşamından alır ve bedenlerin disipline edici yöntemlerle yeteneklerinin artırılması, güçlendirilmesi söz konusudur (Foucault, 2008; Faucault, 2003). Ancak, "bireyleri özne yapan bu iktidar biçimi” (Foucault, 2016: 63), belli sınırlarla, yaşam hakkı tanınan bedenleri ötekilerden ayırır. Bedene yönelik düzenleyici müdahaleler, güvenlik düzeneklerini tesis ederken itaatkar ve toplumun yeniden üreticisi olan özneleri var kılmayı hedefler. "Güvenliğin bir iktidar paradigması olarak ayırt edici özelliği hayatı sadece düzenleyip korumak değil, durumun gereklerine göre yok olmasına göz yummaktır" (Gambetti, 2012: 30). Yaşaması gerekenler toplumsal hiyerarşinin üst basamağında görülenlerdir. Ötekilere göre daha ileride görülen toplulukların yaşamını güvence altına almak için geride konumlandırılanların "ölüme bırakılması" meşrulaştırılır. Böylece, biyolojik bir ırkçılık biçimi olarak insan türünün "aşağı türler yok olma eğiliminde oldukça, anormal insanlar ortadan kalktıkça” daha güçlü, daha sağlıklı, daha çok yaşaması, biyolojik varlığını sürdürmesi sağlanır (Foucault, 2008: 260-261). Günümüzün ardı arkası kesilmeyen savaşları da, iyileştirilmesi gereken insan türünün devamının garantisidir. Foucault, "Onca rejim, yaşamın, yaşamı sürdürmenin, bedenlerin ve ırkın yöneticisi olma sıfatıyla onca insanı öldürterek onca savaşı sürdürebilmişti" diyerek, devam eden savaşların, yaşam hakkı tanınanların ötekilere rağmen varlığını sürdürmesine nası olanak verdiğine işaret eder (2003: 101). Biz ve onlar ayrımı böylece, toplumsal hiyerarşinin üst basamağında konumlandırılanların yaşamsal güvenliği için sürdürülür. Foucault'un, düşünsel temellerini kurduğu nüfusun biyo-politikasının kimlerin yaşamını 
dışarıda bırakarak işlediği sorusu, çerçevesi genişletilerek tartışılmaya devam etmektedir.

Giorgio Agamben (2001), bu tartışmayı “kutsal insan”la sürdürür. Agamben, kutsal yaşamı, egemenin ölümle olan ilişkisi bağlamında tartışmaya açar ve ona göre bu ilişki Foucault'da olduğu gibi belirli bir döneme ait değildir, Batı siyasetinde egemenliğin tesisinde sürekli varlığını sürdürür. Çıplak hayat (zoe) ile siyasallaşma arasında sürekli bir ilişki vardır. "Çıplak hayatın 'siyasallaştırılması'yla -bu eşsiz metafizik görevle- yapılan şey, yaşayan insanın insanlığına karar vermektir” (Agamben 2001: 17). Bu karar, çıplak hayatla, siyasal varoluş arasındaki ikiliğin, dışlama ile dahil etme mekanizmalarının egemenliğin sınırlarını belirleyecek şekilde sürdürülmesidir. Siyasal düzenin temelini sağlayan şey, çıplak hayatı hem siyasal düzenden dışlayan hem de içine hapseden istisnai durumdur (Agamben, 2001: 18). "Kutsal hayat üretilmeden egemen üretilmez. Bu nedenle de biyo-politika analizinin asli işlerinden biri, kutsal hayatın imal edilmesi üzerinden egemenin öldürebilir ile yaşatılabilir arasında çektiği sınırın faş edilmesidir” (Özmakas, 2018: 197-198). Agamben, biyopolitikanın mekânsal analizinin merkezine kampı yerleştirir. Kamp, modern iktidarın yasayı askıya alarak, yasayı askıya alma gücü üzerinden egemenliğini kullandığı ve buradan çıplak bedeni ölüme terk etme yetkisini aldığı, "istisna durumunun kurala dönüşmeye başladığı zaman açılan mekândır” (2001: 201). Yasanın alanının dışında bırakılan bedenler, egemenin karşısında burada çıplak kalır. Agamben'de, modern iktidarın özelliği, yasanın askıya alma halinin istisna olmaktan artık çıkmış olmasıdır. İstisna hali hukuğun özel bir biçimi değildir. Istisna, yasayı askıya alır ve onu iktidarın keyfi kullanım alanına bırakır. Istisna hali, hukuki bir boşlukta siyasal olanın kamplarla kendisini var etmesidir (Agamben, 2001: 33-41). Çıplak bedenlerin dışlanması artık iktidarın mekânsal sınırları belirlemesinin politikasına dönüşmüştür ve bu sadece insanların ölüme terk edildiği, yasanın korumasından uzaklaştırılarak, insan olmadan düşürüldüğü toplama kaplarında değil, egemenin egemenliğini dışlamaya dayalı olarak sürdürdüğü bütün toplumsal mekânlarda geçerli olabilmektedir.

Günümüz siyasetinin karşı karşıya kaldığı yeni gerçek, doğum (çıplak hayat) ile ulus-devletin giderek birbirinden ayrılmasıdır ve işte bizim kamp dediğimiz şey bu ayrışmadır. Artık yerleştirmenin olmadığı bir düzenin (yani hukukun askıya alındığı istisnai durumun) karşısında buna tekabül eden düzensiz bir yerleştirme (yani daimi bir istisna mekânı olarak kamp) vardır. 
Siyasal sistem artık hayat tarzları ve hukuk kuralları vazetmiyor; bunun yerine bunu aşan ve bütün hayat tarzlarını ve bütün kuralları içine alabilen yersizleştiren bir yerleştirmeye (dislocating localization) dayanıyor (Agamben, 2001: 209).

$\mathrm{Bu}$ bağlamda, mülteci kamplarından, kentin gettolarına, güvenli plazalardan, hapishanelere kadar her yer, gücünü mekâna müdahaleden alan biyo-politik stratejilerin sınırlandırdığı ve bedenleri çıplak bıraktığı alanlar olarak düşünülebilir. "Yersizleştiren bir yerleştirme olarak kamp, bugün hala içinde yaşadığımız siyasetin gizli kalıbıdır; havalimanlarımızdaki zones d'attentes ve şehirlerimizdeki varoşlar olarak karşımıza çıkan metamorfozlarını tanıyabilmek için kampın bu yapısını bilmemiz gerekiyor" (Agamben, 2001: 210). Agamben'e (2001) göre, mültecilerden bu kadar rahatsızlık duyuluyor olmasının nedeni tam da bu gizli kalıbı açığa çıkarmış olmalarıdır. Mülteciler, modern egemenliğin orijinal kurgusunu, insan ile vatandaş, doğum ile milliyet arasındaki sürekliliği kopararak krize sokarlar. "Mülteciler, doğum ile ulus arasındaki farkı ortaya çıkarmakla, siyasal alanın gizli önvarsayımını -yani çıplak hayatı- gözler önüne serer" (Agamben, 2001: 158).

Bu noktada, mültecilerin siyasal anlamda değerleri olmayan, özneleşemeyecek kitleler olarak veya yardıma muhtaç mağdurlar olarak gösterilmesi daha net anlaşılır. Bir tür doğal yaşam içinde (bu tehlikeli denizler, yollar olsa da) otantik varlıklar olarak temsil edilirken, ulus-devletin kabul sınırlarındaki vatandaş tanımının dışına düşürülürler ve "çıplak bedenler" olarak savunmasız bırakılırlar. Agamben'in tanımıyla mültecilerin hakları için çalışan insani(yetçi) örgütler de "insan hayatını yalnızca çıplak ya da kutsal hayat figüründe kavrayarak" (2001: 161) egemen güçleri desteklerler. Ruandalı mülteciler yararına yapılan reklam kampanyaları üzerinden Agamben (2001), mültecinin hayatının nasıl "öldürülebilen ama kurban edilemeyen" hayat olarak ve "sırf yardım ve koruma nesnesi” olarak görüldüğünü örnekler: "Para toplamak için fotoğrafı sergilenen ama 'artık canlı olarak görülmesi mucizelere kalmış olan' Ruandalı çocuğun 'yalvaran bakışları', herhalde tıpkı devlet iktidarı gibi insani(yetçi) örgütlerin de ihtiyaç duyduğu çıplak hayatı günümüzde en fazla ele veren şifredir” (Agamben, 2001: 168). Böylece, tecrit edilen, bakışlardan uzaklaşan çıplak hayat ölüm siyasetinin tertibine bırakılır. 
Mbembe (2014), nekro-politika tanımıyla ölümün hangi siyasal, ekonomik ve toplumsal koşullarda normalleştirildiğini ve meşrulaştığını tartışmaya açar. Günümüz modern toplumlarında egemenin, yasaklama, dışlama ve terk etme pratikleri ile ölüm idaresini nasıl kullandığını sorgular. Ona göre, geç modern toplumlarda savaşlar biçimleri, amaçları, mekân kullanımları ve kapsamları açısından oldukça karmaşıklaşmıştır. Artık savaşlar, yüzyılın başında sınırlandırıldıkları alandan gittikçe dışarı taşarak savaşa dahil olan aktörlerin çoğalmasını getirir. Savaş formlarının değişmesiyle beraber, devletlerin taraf olduğu belirli sınırları aşan, insan gruplarının da savaşa dahil olduğu, "disiplinci güçlerin, biyo-siyasal güçlerin ve nekro-siyasal güçlerin birleştiği” yeni bir sömürgeci işgal dönemi yaşanmaktadır (Mbembe, 2014).

Mbembe, "Yaşama, ölüme ve insan bedenine (özellikle de yaralı ya da ölü bedene) verilen yer neresidir? Bunlar iktidarın düzenine nasıl kaydedilirler?" (Mbembe, 2014) diye sorarak, Foucault'un yaşatmaya odaklı biyo-politikasının düşünsel zemininin üzerine ölümü tesis eden nekro-politikayı geliştirir. Nekro-politik iktidarda, bedenin disiplin altına alınmasının yerini bedenin ortadan kaldırıması alır. Nekrosiyasetin işleme alanları tarihsel olarak sömürgeleştirme pratiklerinde, kölelikte olduğu gibi bugünün çağdaş toplumlarının savaşlarında da kuşatma ve işgal pratikleriyle, sokağa çıkma yasaklarıyla sürer. Filistin örneğindeki gibi, "yerel sivil kurumlar sistematik olarak tahrip edilir, kuşatma altındaki insanlar gelir araçlarından yoksun bırakılır", egemenlik yaşamı abluka altına alarak, kuşatmayı süreklileştirir ve "yaşam ölümün iktidarına tabi kılınır” (Mbembe, 2014). İnsan üzerindeki biyo-politik düzenleme mekanizmaları, insanın kuşatılmış ve askerileştirilmiş alanlarda, yaşamsal ihtiyaçlarından mahrum bırakılarak kapatılmasına neden olur.

Mbembe'nin ifadeleriyle, “yaşamın ölümün iktidarına tabi kılınmasının (nekrosiyaset) çağdaş biçimlerinin direniş, kurban/feda ve terör arasındaki ilişkileri köklü bir biçimde yeniden düzenlediği” (Mbembe, 2014) dönemde elbette görünüm alanı da bu politikaları destekleyecek biçimde işler. Judith Butler (2005), görünüm alanını düzenlemenin, neyin gerçeklik sayılıp, neyin sayılamayacağını belirlemenin bir yolu olduğunu söyler. Bu aynı zamanda hangi yaşamın yaşam olarak kabul edildiğini, kimlerin ölümünün ölüm olarak görüldüğünü ve kimin yasının tutulmaya değer olduğunu da belirlemenin yoludur (Butler, 2005: 17). Öyleyse, kimin yasının tutulabilir olduğunu, kimin insan olduğunu ve kimin kaybının kayıp sayıldığını belirleyen normlar, 
neyin görünüp neyin görünmeyeceğini belirleyen egemen temsil biçimlerinden beslenir. Savaşların yarattığı yıkımın, yoksulluğun, göçün ve kaybın hangi bakış açısından görülebileceği üzerinde denetim kurmak, bedene yönelik ayrımcı politikaların devamıdır. Görme alanına getirilen sınırlamalar ve kısıtlamalar, "neyin algı sahası olup neyin olmayacağını, bu sahaya nasıl girileceğini ve sınırları içerisinde neyin kayda düşüleceğini önceden yorumlamanın bir yoludur” (Butler, 2005: 154). Görünürlük alanının sınırları, sadece kimlerin görünürleştirileceği üzerinden değil, görsel temsilin niteliği üzerinden de belirlenir. Butler’a göre, normatif iktidar iki ayrı biçimde görünürlük alanına müdahale eder: "biri yüzü insandışı olanla sembolik olarak özdeşleştirerek, sahnedeki insanı idrak etmemizi önleyerek işler; diğeriyse radikal silme üzerinden işler, öyle ki, bir insan hiç olmamış, bir hayat hiç olmamış, dolayısıyla bir cinayet gerçekleşmemiştir" (2005: 148-149).

\section{“Çerçevede” Mültecilik}

Mültecilerin bugün yaygın dolaşımdaki görüntüleri bir yanıyla Butler'ın, "sahnelenen insanı idrak etmemizi önleyen imgeler" (2005: 148-149) tanımının içinde düşünülebilir. Mültecilerin aslında toplumsal hiyerarşinin hangi basamağında görüldüğü, biz ve onlar ayrımının görsel alanda nasıl işletildiği hakkında fikir verir. Eşyalarını çoğu zaman çuvallarla veya sırt çantalarıyla taşıyan, üstleri başları kir pas içinde, hareket halindeki kalabalıklardır çerçevelenen. Botlar, tel örgüler, turuncu yelekler, yakın plan çoçuk yüzleri, bebekleri kucağında çaresiz anneler...1 Olmak istemeyeceğimiz, bizim dışımızda, varlık alanımızın uzağında ve "insana yakışmayacak koşullarda" yaşayanlara ait görüntüler. Önyargı, bireysel varoluşu, bireye özgü olanı, grup kimliği içinde eriten, önemsizleştiren, genellemeci, olumsuz tutum ve kanaatlerdir (Göregenli, 2013: 26). Burada gerçek deneyimlere dayanmaz. Biz ve onlar ayrımına dayanır. Öteki, ait olduğu düşünülen grup kimliğinden hareketle tanımlanır. Bir yerden bir yere kötü koşullar içinde göç eden kalabalıklar imgesi, yürürken, tel örgüleri geçmeye çalışırken ya da botlara sıkışmışken tekrar tekrar kullanıldığında biz ve onlar ayrımı

\footnotetext{
1 Google arama motoruna, "mülteciler" ya da "göçmenler" yazılarak görsellere ulaşıldığında, burada sözü edildiği gibi birbirini tekrarlayan görsel imgelerle karşılaşılır. Yaygın dolaşımda olan bu imgeler, sosyal medyada, gazetelerde kullanıldığı kadar insani yardım örgütlerinin afişlerinde, bültenlerde, raporlarda ve akademik araştırmalarda da kullanılıyor.
} 
güçlenir. Böylece, kalın çerçeveyle çizilen mültecinin görsel imgesi, kimliği başkasının görüntüsünden hareketle şekillendiren belleklere yerleşir.

Fotoğraf makinesini, "emperyalizmin görme rejiminin ürünü” olarak tanımlayan Ariella Azoulay, fotoğrafçıların her şeyi gösterme hakkını, konu edindiği insanları onların iradesi ve rızası olmadan çekme hakkını nereden aldıklarını sorgular (2018a). Ona göre bu sorunun yanıtı, fotoğrafın tarihsel olarak egemen güçlerin, sömürgeci bakışın hizmetine nasıl sunulduğu tartışmasının içindedir. İnsanların; savaşların, yıkımların, göçlerin figürüne dönüştürülebilmesi tam da bu yıkımın aktörlerinin çerçevenin dışında tutulmasıyla mümkün olmuştur. Her şeylerini, dolayısıyla göstermeme haklarını dahi kaybetmiş olanların fotoğrafları çekilebilir, "başkalarının dünyası incelenecek, taktir edilecek veya temellük edilecek malzemeler" olarak görülebilir (Azoulay, 2018b). Azoulay, bugün az gelişmiş bölgeler olarak adlandırılan yerlerden zorunlu nedenlerle Avrupa'ya ve ABD'ye göç etmeye çalışan milyonlarca insanın, bir zamanlar yine zorla doğal ve kültürel varlıklarından koparıldığını hatırlatır. Sömürge pratikleri altında yıllarca kendilerinin ve atalarının yaptığı nesnelerden mahrum edilen kişiler (eserleri müzelerde, arşivlerde kütüphanelerde kapalı tutulan insanlar) "emperyalizmin ülkelerinde yarattığı yıkıcı koşullardan kaçmaya çalışırken sınırlarda çekilen fotoğraflarında nesnesiz ve dünyasız göçmenler olarak görünüyorlar” (Azoulay, 2018c). Bir zamanlar onlara ait kültürel nesneleri kendi coğrafyalarından koparan ve müzelerinde sergileyen ülkelerden sığınma hakkı arayan insanlar, geçmişlerinden, öteden beri maruz kaldıkları yoksunlaştırmadan, şiddetten, tarihlerinden koparılmış figürler olarak sunulurlar.

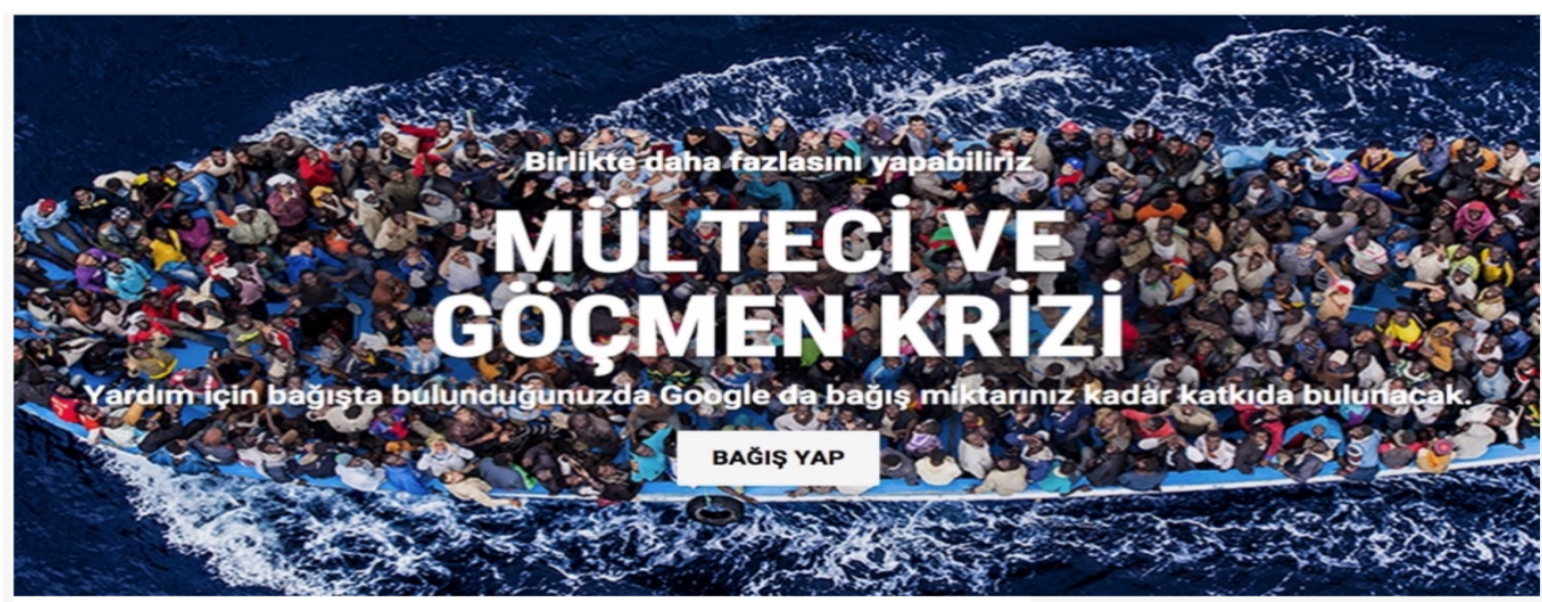

Görsel 1: Google Yardım Kampanyası.

Kaynak: https://www.campaigntr.com/googledan-multeci-ve-gocmen-krizi-icin-yardim-kampanyasi/ 
Bu sadece çarpıcı haberler yakalamaya çalışan medyanın ürettiği bir söylemden ibaret değildir. Göçmen ve mültecilerin yararına çalıştığını savunan örgütler de insani yardım kuruluşları da mülteci bedenine yakıştırılan figürleştirmeleri destekler nitelikte söylem ve görüntü üretirler. Kendi tarihlerinden koparılmış, zamansız ve mekânsız gösterilen kalabalıklar, çoğu zaman estetize edilmiş bir doğa parçasının içinde, tehlike altında kurtarılmayı beklerken, görsel yüzeyden kayıp giden birçok soru yanıtsız kalır: Gerçekte bu insanlar kim? Nereden kaçıyorlar? Neden bu koşullar altındalar? Onların yaşamları, kimlikleri, aidiyetleri, coğrafyaları, kültürleri ve yaşam deneyimleri hakkında ne biliyoruz? Bilmek istiyor muyuz?

Denizin maviliklerine sıkışmış, yüzlerini dahi seçemediğimiz kişilere ait görüntülerin totalleştiriciliği, azınlıklara karşı, kendilerini o azınlık dışında gören hakim sınıfların önyargılarını besler. Kimlikleri belirsiz, isimleri olmayan, göçün ikonuna dönüştürülmüş "belgesiz" yabancılar, yardımın nesnesi olsalar da toplumda göçmenlere ilişkin yerleşik önyargılara karşı herhangi bir argüman oluşturmazlar. Tekrar tekrar üretilen imgeler, görsel dilde kodlanan bir tür dışlama mekanizmasına hizmet ederler ve bizden olmayanlar ayrımını güçlendirirler. Görsellerdeki kişilerin kayıplarını, acılarını duyumsayabildiğimiz herhangi bir alan bırakmazlar. Theodor Adorno (2011), Otoriteryen Kişilik’te önyargıların, yöneldiği nesnesinden neredeyse bağımsız veya yüzeysel bir ilişki içinde olduğunu yani imgesel olduğunu tespit eder. Ona göre önyargılar fantezilerden beslenir ve hiç temas kurulmamış imgesel düşmanın sahip olduğu varsayılan aşırı güç düşüncesiyle ilgilidir. "Ülkesini terk etmeye zorlanmış göçmen, davetsiz konuk olmayı isteyen ve bütün dünyayı istila etmeye niyetli biri gibi ortaya çıkmaktadır" (Adorno, 2011: 36). Dış gruba yüklenen bu her şeye kadirlik fantezisi, yansıtma mekanizmasıdır ve dış tehdide, dış düşmana (yabancı) karşı 'biz' duygusunu güçlendirir. Toplumsal yabancılaşmayla baş etme becerisini artırma işlevine sahiptir (Adorno, 2011: 31-40).

Görsel dilde tekrarlanan yığınlar imgesi, çoğu zaman yüzlerini dahi seçemediğimiz insanların daha önce de yaşamları olduğunu düşünmemize izin vermez. Onlar sanki göç etmeye başladıklarında, kalabalık gruplar olduklarında, yollara düştüklerinde varlık edinmişlerdir. Sürekli grup kimliği vurgulanarak totalleştirici bakışa hizmet eden mültecilere dair görsel imgeler, onların koşulları hakkında bilgi vermekten çok, uzaktan bakan göz açısından şiddetin belli bir türünü, oldukça sınırlı 
bir çerçeve içinden tanımlar. Görseller göç halindeki kalabalıkların ait oldukları yerlerden koparıldıklarını imlese de failler hakkında herhangi bir soru sordurmazlar. Burada mesele, mültecilerin koşullarının anlatılması, yaşanan olayların kaydının tutulması, yaşadıkları kayıpların dünyanın geri kalanına aktarılması, işlenmesi ve yardım çağrısında bulunulması meselesinden çıkar. Yurtlarından kaçmak zorunda kalanlarla, göç halinde olanlarla bu görüntüler aracııığıyla tanışan mülteci olmayanların mültecileri nasıl algıladığı, onlara dair zihinlerindeki "hayali" bölgeleri nasıl tamamladıkları meselesine dönüşür. Butler (2015) 'çerçeve'den söz ederken, medyada dolaşıma giren, belirli bir duygu politikasını hedefleyen, gerçeklik üretim alanı olarak görülebilecek savaşlara veya şiddet olaylarına dair fotoğraflara işaret eder. Bu tür fotoğraflar ile egemenler, neyin görünüm alanına çıkacağını önceden belirlerler, 'temsil edilebilirlik sahası' hangi hayatların insan ve canlı hayatı sayıldığına dair bariz veya zimmi normlarla düzenlenir. Nihayetinde görsel imge, konu edindiği insanlara ve topluluklara yönelik belli bir yorum oluşturur, algılarımızı ve düşüncelerimizi yönlendirir (Butler, 2015: 70-75).

Görüntüler empati talep ederken dahi ırksal üstünlük paradigmasını desteklerler, üçüncü dünya ülkelerinden gelen kalabalığa, güçlü olanların bakış açısından bakmaya davet ederler. Suriye'deki savaştan kaçarak Bodrum'dan Yunanistan'a geçmeye çalışırken ailesiyle birlikte bindiği lastik botun devrilmesi sonucu hayatını kaybeden üç yaşındaki Alan Kurdi'nin kıyıya vuran ve ikonik hale gelmiş fotoğrafının yarattı̆̆ı etkiyi araştıran Tuğba Taş (2017), bu tür fotoğrafların ilk bakışta savaşta yaşananlara dair empati kurma olanağı yarattığı düşünülse de fotoğrafa gelen yorumların ayrıntılı analizinin sonucu farklılaştırabileceğini gösterir. Alan Kurdi haberlerine yapılan okuyucu yorumları, sosyal medya paylaşımları her zaman olumlu değildir, ırkçı ve ayrımcıdır da. Bu da izleyicilerin görsel imgeleri yorumlarken görüntünün tekilliğinden ziyade görüntülerin alımlandığı bağlamı önceleyen tepkiler verdiklerini gösterir. Alan Kurdi ile ilgili yorumlarda, genel olarak mültecileri hem kurban hem de suçlu gösteren normatif çerçeve tekrarlanır. İzleyicilerin zihninde medyada mültecilerle ilgili egemen söylemin yarattığı kalıp yargılar vardır. Bu yargılar bir yandan "kaçak" yolları deneyenlerin sonuçlarından kendilerinin sorumlu olduğu vurgusunu yaygınlaştıı öte yandan kurbanlaştırma da insanlıktan çıkarmanın yollarından birine dönüşür (Taş, 2017: 3-28). 
Böylece, medyada yaygın dolaşımda olan mültecilere dair görsel imgeler, biyopolitik alanın sınırlarını korurlar. Tehlikeli yolculukları aşmayı başarmış olanların nasıl yaşadıkları, hayatı yeniden nasıl kurdukları egemen görsel temsilin konusu değildir. İster mültecilerin yerleştirildiği çadır kentler olsun, ister tel örgülerle çerçevelenmiş yürüyüşleri olsun, ister ölü bedenlerinin vurduğu sahil kenarı olsun hep bu "sınırda tutulma" haliyle karşılaşılır. ${ }^{2}$ Bugün milyonlarca insanın yerinden edildiği, yer değiştirdiği dünyamızda, görsel dilde bu sınırlar ötesine geçebilecek, seyirci konumumuzu sarsacak, ötekine etik sorumlulukla yaklaşmamızın kapısını aralayacak görsel imgelere ihtiyaç vardır. Mültecilere dair önyargıların güçlenmesine hizmet eden egemen temsilin sorgulanmasıyla birlikte, kurban ya da tehlikeli yabancı çerçevesine sıkıştırılmış görselleştirmelerin ötesine geçebilecek, kaybı, yokluğu anlatabilecek dilin olanakları nasıl yaratılabilir. Bu soruya yaklaşırken daha en başta kendi kaybını anlatabilen, kendi acısını dile dökebilen "öznelerin" temsil sahnesini kurmasının elzem olduğunu vurgulamak gerekir. Kaybı yaşayanların kayıplarını, yaslarını, acılarını kendi öykülerini anlatan failler olarak aktarmalarına izin verilmedikçe bunun anlamı, seyircisi konumunda kaldığımız kırılgan hayatları, "güçsüzlüğümüzün onlara armağan edebileceği yegane şeyden, bellekten de yoksun bırakmak" (Adorno, 1999: 124) olacaktır. Kendi belleklerinin taşıyıcısı olma hakkı, kendi acısını, kaybını gösterme, yasını tutma çabası, mülteciler de dahil yaşam hakkı gasp edilmiş dünyanın çeşitli yerlerinde yaşayan milyonlarca insanın var olma mücadelesinden ayrı düşünülemez. Şili'de karşımıza çıkan Arpillera, bu mücadelenin örneklerinden biridir. Butler'ın tanımıyla "insanı zayıflığı ve kırılganlığı içinde görünür kılan" (2015: 77), yaşadığı zulmü, baskıyı yine kendi görsel imgelerini yaratarak var olma mücadelesine dönüştürebilen, buradan kendi hikâyesini kuran örneklerden biri. İlerleyen tartışmada yer verilen Arpillera, yaşam hakkı tanınmayan bedenlere yönelik ayrımcı görsel rejimin çerçevesine sızan imgelerdir ve mülteci bedeninin yerleşik temsilini aşmaya dair sorgulamalara kaynak olur. Dikkatleri, görünüm alanına dahil edilmeyenlere, yok sayılanlara yöneltir. Algı sahasını bu kez kendi iradeleriyle yönlendirenler, savaşların, şiddet olaylarının, göçlerin getirdiği acıları temsil ettiği iddiasında olan görsel imgelerin

$2 \mathrm{Bu}$ tür temsillere verilebilecek güncel linkler için bakınız: Türksam Göç Bülteni http://turksam.org/konu/goc-bulteni Erişim tarihi: 10 Aralık 2019; Hepimiz Göçmeniz Grubu Broşürü https://gocmeniz.org/broşür Erişim tarihi: 10 Aralık 2019; BM Mülteciler Yüksek Komiserliği Web Sayfası https://www.unhcr.org/tr/ Erişim tarihi: 21 Kasım 2019. 
yüzeyde bıraktıklarının ötesinde; şiddeti, kaybı, yası anlatmanın başka yollarını aralarlar. Bu her şeyden önce geçmişte olan yıkımların, acıların, kaybedilenlerin, toplumsal belleğin inşasında yok sayıların lehine hatırlanması ve aktarılması talebidir.

\section{Kaybı Parça Parça İşlemek: Arpillera}

Şili'nin sosyalist başkanı Allende ve hükümetinin 11 Eylül 1973 tarihinde askeri darbe sonucu devrilmesinin ardından, 17 yıl boyunca diktatörlük rejimi altında ülkeyi yönetecek olan Pinochet iktidara gelmiştir. Bu süre boyunca binlerce kişi işkenceye ve insanlık dışı muameleye maruz bırakılmış, işlerinden edilmiş ve binlerce kişi öldürülmüş/kaybedilmiştir (Freire vd., 2017). ${ }^{3}$ Arpilleralar, bilinen diğer adıyla Arpilleristas, 1974 yılında kayıp yakını kadınların bir araya gelerek üretmeye başladıkları, farklı renk ve dokudaki kumaşları kesip dikilerek bir araya getirdikleri, görsel imgeler yoluyla belirli olayları anlattıkları yama işleridir (patchwork). Arpilleralar, darbe süresince ve ardındaki diktatörlük yılları boyunca kadınların seslerini duyurabildikleri, yaslarını tutmakta ısrarcı oldukları bir toplumsal hareket meydana getirmiştir. Üretilen işlerin satılmasıyla ekonomik alan da yaratılmış, böylece kayıp yakınlarının ihtiyaçları karşılanarak mücadelenin fonlanmasına katkı sağlanmıştır.

Arpilleralar darbe süreci ve sonrasındaki uygulamaları, gece baskınlarını, işkenceleri, eksik devam edilmek zorunda bırakılan hayatı, kayıplarını arayan kayıp yakınlarını, onların mücadelelerini, kaybedilen kişileri, yani süreç boyunca yaşanmış ve üretildiği dönemde gerçekleşmeye devam eden olayları hikâye eder. Tal Morse (2016), yaşamları hakkında izleyiciye sunulanlar dışında bilgi sahibi olunmayan ölümlerin yası tutulabilir hayatlar olup olmadıkları üzerine analiz yapar. Medya dolayımıyla karşılaşılan ölümlerin yası tutulabilir dolayısıyla hayat olarak kavranabilmesinin imkanlarından biri, izleyicinin tanıklığını sağlayacak bir hikâyenin üretilmesidir (Morse, 2016: 11-12). Mülteci ölümlerinde isimsiz kurbanlar yaratılarak ölümler aynılaştırılır, bedenler anonimleştirilir. Oysa, bir hikâyeden yoksun bırakılmış olsa dahi bütün ölümler biriciktir.

\footnotetext{
${ }^{3}$ Şili'de darbe sonrası yaşanan şiddetin boyutlarıyla ilgili Birleşmiş Milletler Barış Enstitüsünün ayrıntılı raporu için bkz.

https://www.usip.org/sites/default/files/resources/collections/truth_commissions/Chile90Report/Chile 90-Report.pdf
} 
Arpilleralar her kaybın kendi biricik hikâyesini, ortak deneyimin içinden kurarlar. Kendi kişisel hikâyelerini anlatmak, kayıplarını gösterebilmek, yaslarını tutabilmek adına bir araya gelen kadınlar, kolektif bir şekilde ilmek ilmek bu yamaları yaparlar. Yaşadıkları şiddeti aktarmanın, acılarla dolu geçmişle yüzleşmenin, yok sayılan yaşamları görünür kılmanın yolunu ararlar. Adorno (1999), toplumsal travmaların, soykırımların, savaşların üzerinden zaman geçtikten sonra nasıl ele alındığını tartıştığı makalesinde, "geçmişin işlenmesi ne demektir?" sorusunun titizlikle değerlendirilmesi gerektiğini söyler. Çünkü suçta ortaklığını görmek istemeyenler için, geçmişin işlenmesindeki kasıt geçmişin ciddi biçimde ele alınmasından ziyade, geçmişten kurtulmak, hatta yaşananları bellekten bile silmek anlamına gelebilir. ${ }^{4}$ Oysa, geçmişin işlenmesi, olup bitenlerden kurtulmak ya da ortak suçu savuşturmak değildir. Ne kadar kavranamaz olsa bile yaşananları kavramaya çalışmak ve yüzleşmeye çalışmaktır. Bu bağlamda, toplumların geçmişle ne kadar yüzleşebildiğini sorgulamak, geçmişte olanları mümkün kılan koşulların hala toplum içerisinde varlığını sürdürüp sürdürmediğini tartışmakla anlaşılabilir. Ancak bu şekilde zorbalıkların geçmişin bir yerinde meydana gelmiş ve artık bitmiş olmasının ötesinde, bugün hala yaşanmasının “nesnel potansiyeli” görülebilir (Adorno, 1999: 121-137). O halde, yıkımla dolu geçmişi anlatmanın yollarını aramak, şimdiye ait bir mesele olarak karşımızda duruyor. Karşılaşma, yüzleşme, anlatma, işleme belki de birbirine değme meselesi. Arpillera işleri, savaşlar, şiddet olayları, göçler karşısında en kırılgan olan gruplardan kadınların kendi öznelliklerini kurma çabasıdır. Kadınlar onları "ideal kurbanlar" olarak gösteren çerçeveyi kırmış, şiddet karşısında, yokluk karşısında kadın dayanışmasının gücünü temsil sahnesine taşımışlardır.

Burada her Arpillera üreticisi kadın bir hikaye anlatıcısı, tanık olarak karşımıza çıkar. Kullanılan kumaşların bir kısmı öldürülmüş olan, kaybedilmiş olan kişilerin kıyafetlerinden gelir ve kaybın sadece temsil biçimiyle değil dokusal olarak da işlenmesine olanak tanır. Renkli kumaşlarla oluşturulan bu görsel imgeler, uzaktan

\footnotetext{
${ }^{4}$ Adorno, Geçmişin Işslenmesi Ne Demektir? makalesine işleme kelimesinin Almanca'da kullanılan iki ayrı biçimine dikkat çekerek başlar. "Aufarbeitung" kelimesi birikmiş işlerin tamamlanması, tatsız yükümlülüklerin yerine getirilmesi hatta baştan savılması gibi yan anlamlar taşır. Adorno, bu kullanımdaki anlamın geçmişle yüzleşmek, geçmişte olanların üstesinden gelmek karşılıkları için yeterli olmayacağını vurgulayarak bunun yerine "Vergangenheitsbewältigung" kelimesini seçer. Böylece geçmişin "işlenmesini" (aufarbeitung) geçmişin üzerinde ciddi biçimde çalışma, geçmişle ciddi biçimde hesaplaşma (verarbeitung) fikrinden ayırır. (Adorno,1999: 137).
} 
bakıldığında içinde sevimli figürler barındırdığı kolayca düşünülebilecek olana yakından bakmanın bir çağrısı gibidir. Bu görselleştirmelerde, egemen medyada yaygınlaştırılan doğrudan şiddet temsillerinin aksine, bizzat olayların tanıkları yaşadıklarının hikâyesine davet eder. Yaklaştıkça, anlatının gerçekliğiyle yüzleşilir, baktıkça imge kendini açar, kayıp bizzat kayıp duygusunu yaşayanların yarattığı görsel imgelerle bize ulaşır.

Jacques Ranciere (2015: 64), mutabakatı/uzlaşıyı (consensus) "duyumla anlam arasında, yani duyumsal bir sunum tarzıyla bunun verilerinin yorumlanma rejimi arasındaki uyumu ifade eder" şeklinde açıklar. Başka bir deyişle, mutabakat/uzlaşı düşünsel ve edimsel farklarımıza rağmen gösterileni/temsil edileni algılayış biçimimizin ortaklaşmasıdır. Sanat ve siyasetin birbirleriyle temas halinde oldukları nokta burasıdır. Çünkü sanat ve siyaset duyulur hissedilir olanın paylaşılma rejimidir. Duyulur-paylaşımı (partage du sensible) Ranciere tarafından "yerlerin ve kimliklerin bu dağılımı ve yeniden dağılımı; mekânların ve zamanların, görünür ile görünmezin, gürültü ile sözün şekillenmesi” olarak açıklanır (2014: 29). Bu uzlaşı zemininin yıkılması için duyumsanabilir olanın paylaşııma rejiminin değiştirilmesi gerekir. Çeşitli duyusallık rejimleri arasında çıkacak olan uyuşmazlık, uzlaşı (mutabakat) zemininin kırılmasına neden olur. Uzlaşı zeminini ortadan kaldırmak da duyulur-paylaşımı rejimini değiştirerek ona yeni özneler ve nesneler dahil ederek, görünür olmayanı görünür kılarak mümkün olur (Ranciere, 2014: 29). Ranciereci anlamda estetik, duyulur-paylaşımı rejimini değiştirendir. Estetikle birlikte yeni bir deneyim alanı yaratılmakta, yeni bir görme, görülme ve gösterme pratiği oluşmakta; zamanın ve mekânın kullanımı değişmekte, uzlaşı zemini ortadan kalkmaktadır.

Darbe döneminde üretilen Arpilleralar insanların görmediklerinin, görmek istemediklerinin, konuşmak -bilmek- hissetmek istemediklerinin yüzeye çıkmış halleridir. Yapılmaya başlandıkları andan itibaren darbe döneminin mutabakat zeminini sarsmışlardır. Kayıp yakınları için yeni bir kolektivitenin kurulabilmesini sağlamışlardır. Yası tutulamaz ilan edilenin yasının tutulmasındaki politik ısrarı Ranciereci bir noktadan estetik bir deneyime dönüştürmüşlerdir. Pek çok Arpillerada kullanılan ve tekrarlanan basit soru "Neredeler?" (Donde Estan?) hem politik hem de estetik bir görsel imge olarak karşımıza çıkar. Bu soru hem bir adalet arayışının yüzeye çıkması hem de kamusal senaryoda görsel imgelerle yasın sahiplenilmesinin yoludur. 
Yas tutma süreci, yas tutan kişinin/topluluğun/toplumun, yitirilen şeyin zihinsel temsilini hatırlaması, gözden geçirmesi ve bu ilişkiyi anlamlandırmak üzere gerçekleştirilen zihinsel etkinliklerin tümü olarak tanımlanabilir (Kaptanoğlu, 2009: 214). Ancak, Butler'ın vurguladığı gibi bu süreç kimlerin kaybının kayıp olarak görüldüğü ve kimlerin yasının kamusallaşabildiğine bağlıdır. "Yaşamlar farklı şekillerde desteklenir ve sürdürülür, insan yaralanabilirliği dünyaya radikal olarak farklı biçimlerde dağılmıştır. Kimi yaşamlar had safhada korunacak ve kutsallık iddialarının ilgası savaş güçlerini harekete geçirmek için yeterli olacaktır. Öteki yaşamlar böyle hızlı ve hiddetli bir destek görmeyecek ve hatta 'yası tutulabilir' olma niteliği bile kazanamayacaktır” (Butler, 2005: 46). Bu noktada yas hiyerarşisinden söz edilebilir. Bu hiyerarşi, iktidarın belirlediği normlar üzerinden ayrımcı bir şekilde kurulur. Bugün zor koşullarda hayatta kalmaya çalışan binlerce mülteci gibi iktidarın sınırlarını belirlemiş olduğu normlar dışında kalan hayatlar yaşanmamış ve yası tutulabilir olmayan hayatlardır.

Tıpkı bugün göç yolunda binlerce insanın yaşamı gibi, Şili'deki darbe ve ardından devam eden dikta rejiminde muhalif konumda bulunan kişilerin yaşamları da değersizleştirilmiştir. Darbe sürecinde yaşanan pek çok hak ihlali, işkence, zorla alı koyma ve 'kaybetme' vakalarına dair yasal bir işlem yapılamaması, faillerin cezalandırılamaması bunun en büyük örneklerinden biridir. Kayıp yakınlarının bir araya gelerek anonim olarak yapmaya başladıkları Arpillera işleri aynı zamanda bir yas tutma mücadelesidir. Kendi tanıklıklarını, kayıplarını, acılarını paylaşan kadınlar toplumsal ve bireysel olarak yaşadıkları travmayı yüzeye taşırlar. Sara Ahmed'in söylediği gibi acı “ona tanıklık eden kişilerle ilişki içerisinde (...) 'yüzeye çıkar’ ve varlığını doğrular (2014: 47). Yüzeye çıkan acının bir yüzeye aktarılması, bu aktarımın farklı kumaş parçalarının bir araya getirilerek anlatılan bir hikâyeyle, bir anla oluşu travma ve yas tutma süreçleri açısından değerlidir. Hayatın kırılmış olduğu, bir kaybın boşluk yaratmış olduğu anda, boşluğun yerine geçecek, doldurmaya çalışacak bir temsil yaratmanın olanaksızı̆̆ı, "Neredeler?" gibi basit ama bir o kadar da önemli bir soruyla ve ayrıntıdan yoksun basit bir dikiş iziyle vurgulanır. Boşluğun yerini hiçbir temsil biçiminin dolduramayacağının altı çizilerek politik bir duruş sergilenir. "Arpilleralar, sadece bir tekstil parçası gibi görülebilir, oysa sanatçısı hikâyeyi anlattığında sizi adeta kalbinizden vurur. Tekstil parçası tamamen farklı bir anlam taşımaya başlar, örneğin kravattan alınan bir parça, aslında öldürülen birinin boynunda 
bulunan bir giysi unsuruydu" (Oyman, 2019: 609). Temsil sahnesine bu şekilde taşınan işler gerçeğin yerini almaya çalışmaz. Onun sadece estetik politik bir hatırlatıcısı, ısrarı olurlar. Kadınlar, kimsenin olaylardan söz edemediği zamanlarda "sesli bir ifade olmaksızın, hatıralarını tarihe kazımak için geleneksel sanatlarından yararlanmışlar" (Caldwell, 2012) ve kayıpları etrafında kolektif bir hafıza yaratabilmişlerdir. Caldwell, bu yolla kadınların kendi bilgi ve deneyim alanlarının içinden, geleneksel zanaatlarını kullanarak politik söz söylemenin imkanını yarattıklarını vurgular. Bu hareketle kadınların Şili'de siyasete ve topluma katılma biçimleri değişmiş, toplumsal cinsiyet normlarıyla, kadınlara geleneksel olarak verilen rollerle mücadele alanları genişlemiştir. Kadınlar işlerini yapmak için kurdukları gizli atölyelerde sadece yama yapmamışlar, sosyal ve politik olarak dayanışmanın sayısız yollarını bulmuşlardır. Atölyeler gittikçe dayanışma merkezlerine dönüşmüştür ve buradan kayıplarını bulma talebinin yanısıra işsizlik, gıda eksikliği gibi gündelik yaşam intiyaçları etrafında örgütlenen bir hareket doğmuştur (Caldwell, 2012).

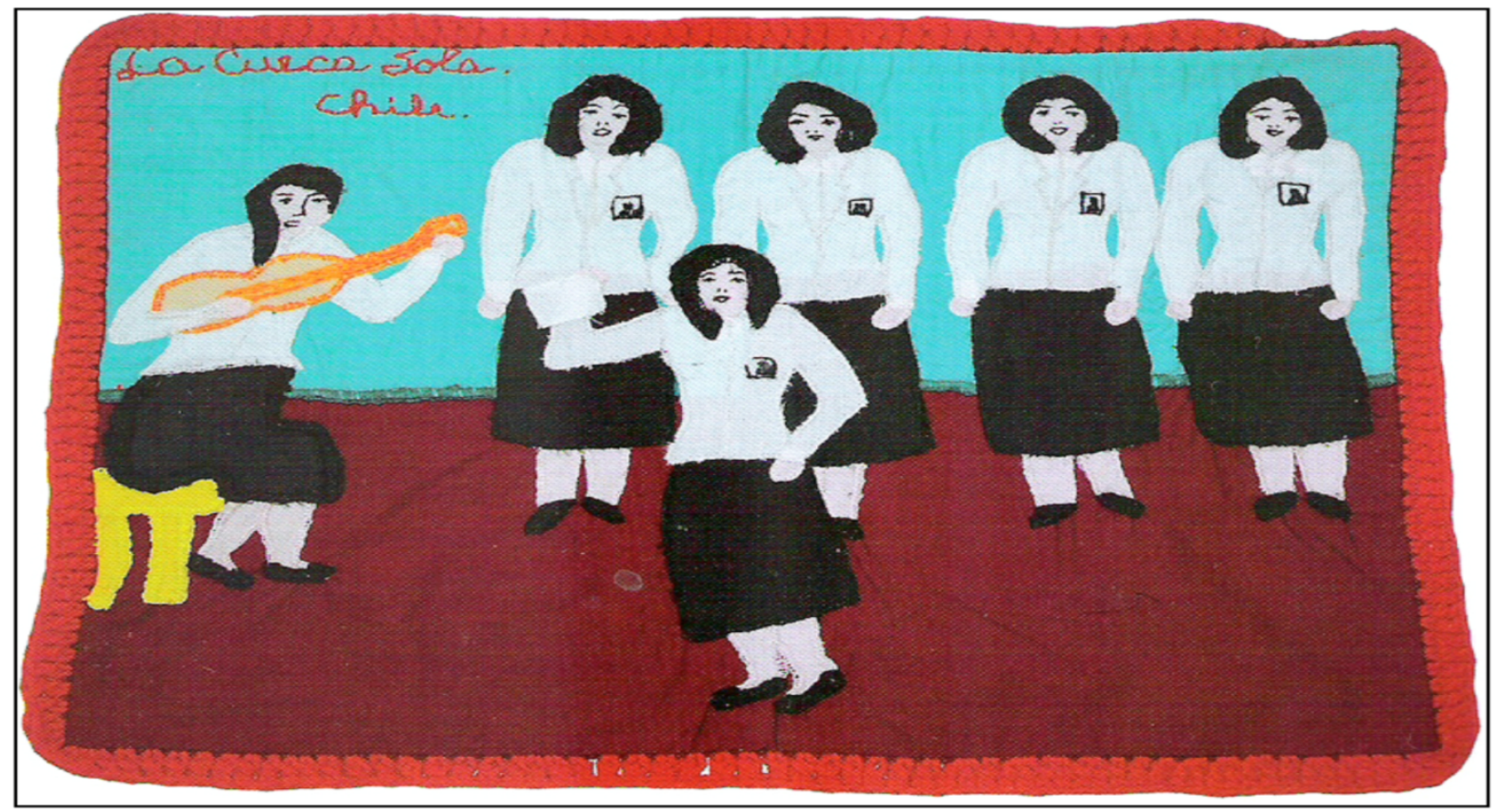

Görsel 2: Violeta Morales, La Cueca Sola (They Dance Alone), 1989. Kaynak: Marjorie Agosín, Tapestries of Hope, Threads of Love: The Arpillera Movement in Chile, 2nd ed. (Lantham, MD: Rowman \& Littlefield Publishers, Inc., 2008), plate 23. Aktaran: (Cadwell, 2012). 


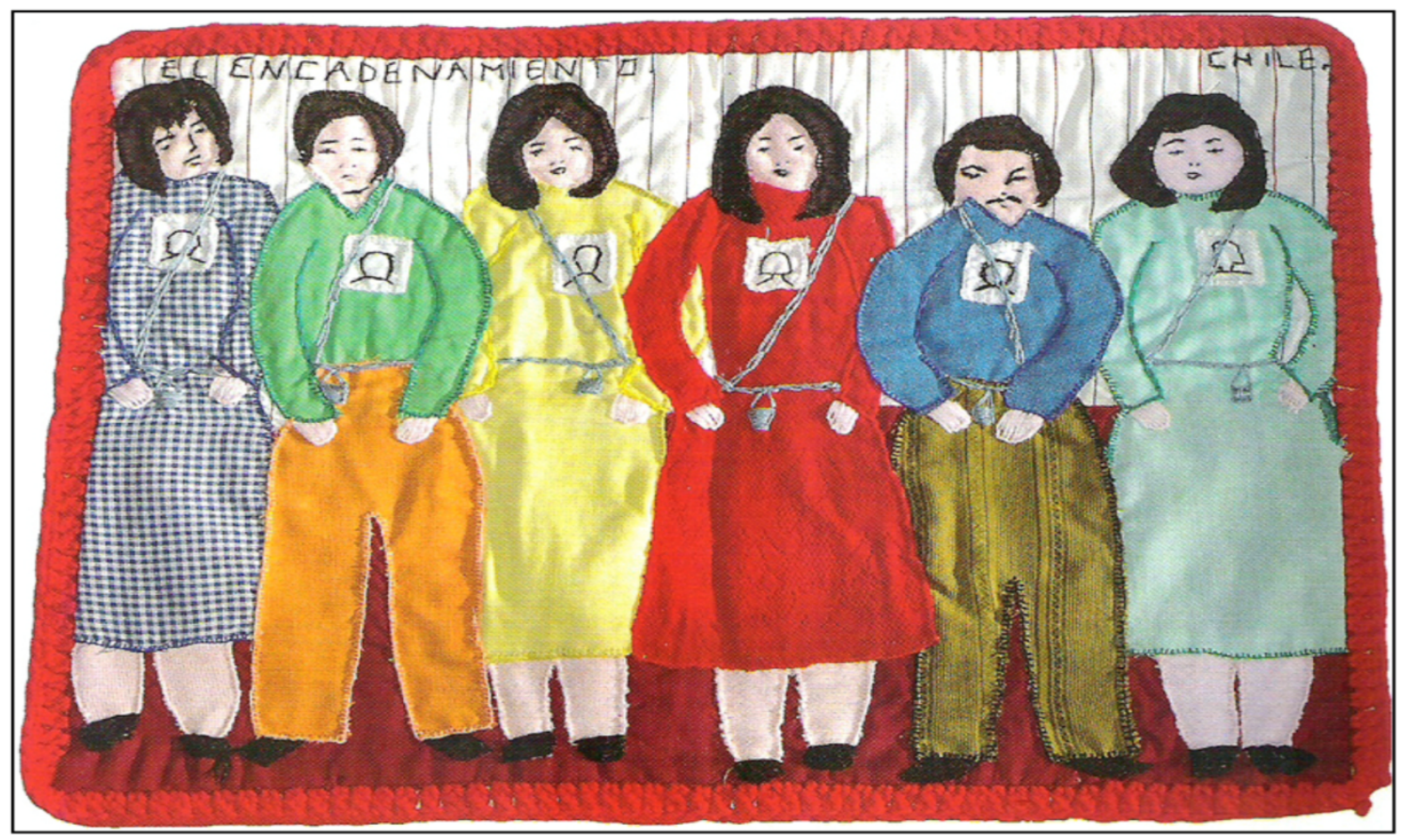

Görsel 3: Mireya Rodriguez, El Encadenamiento (The Chaining), 989. Kaynak: Marjorie Agosín, Tapestries of Hope, Threads of Love: The Arpillera Movement in Chile, 2nd ed. (Lantham, MD: Rowman \& Littlefield Publishers, Inc., 2008), plate 13. Aktaran: (Cadwell, 2012).

Judith Butler kırılganlık, yaralanabilirlik ve tutulamayan yas kavramlarından bahsederken iktidar tarafından belirlenmiş normlar dışında kalan hayatlar için "Yasları tutulamaz çünkü hep kayıptırlar, ya da daha ziyade hiç olmamışlardır ve öldürülmelidirler, çünkü ölülük halinde inatla yaşamayı sürdürüyor gibidirler... Ötekinin gerçeklikten çıkarılmasının anlamı onun ne canlı ne ölü olduğu, tükenmeksizin hayaletimsi olduğudur" tanımlamasını yapar (2005: 48). Hiç temsil edilmemiş olmanın radikal silme aracı olarak işlemiş olduğu sistemde, zaten daha önceden tasarlanmış olan temsil sahnesine, sahnenin/çerçevenin izin verdiği ölçüde çıkmış olmak da hayaletimsiliğin sona ereceği anlamı taşımaz. Bu noktada, çerçeveyi gösteren ya da kıran, temsil sahnesini değiştiren yeni biçimlerin üretilmesi, yasının tutulmasına izin verilmeyenlerin mücadelesinde önemli bir yerde durur. Arpilleralar, kumaş parçalarının özgün bir biçimde bir araya gelmesiyle yaşamı ve ölümü yok sayılan bedenlerin imgesi haline gelirler ve kadınların yaşadıkları kaybın etrafında ortak hafızayı canlı tutma mücadelesinin "iz"leri olurlar. 


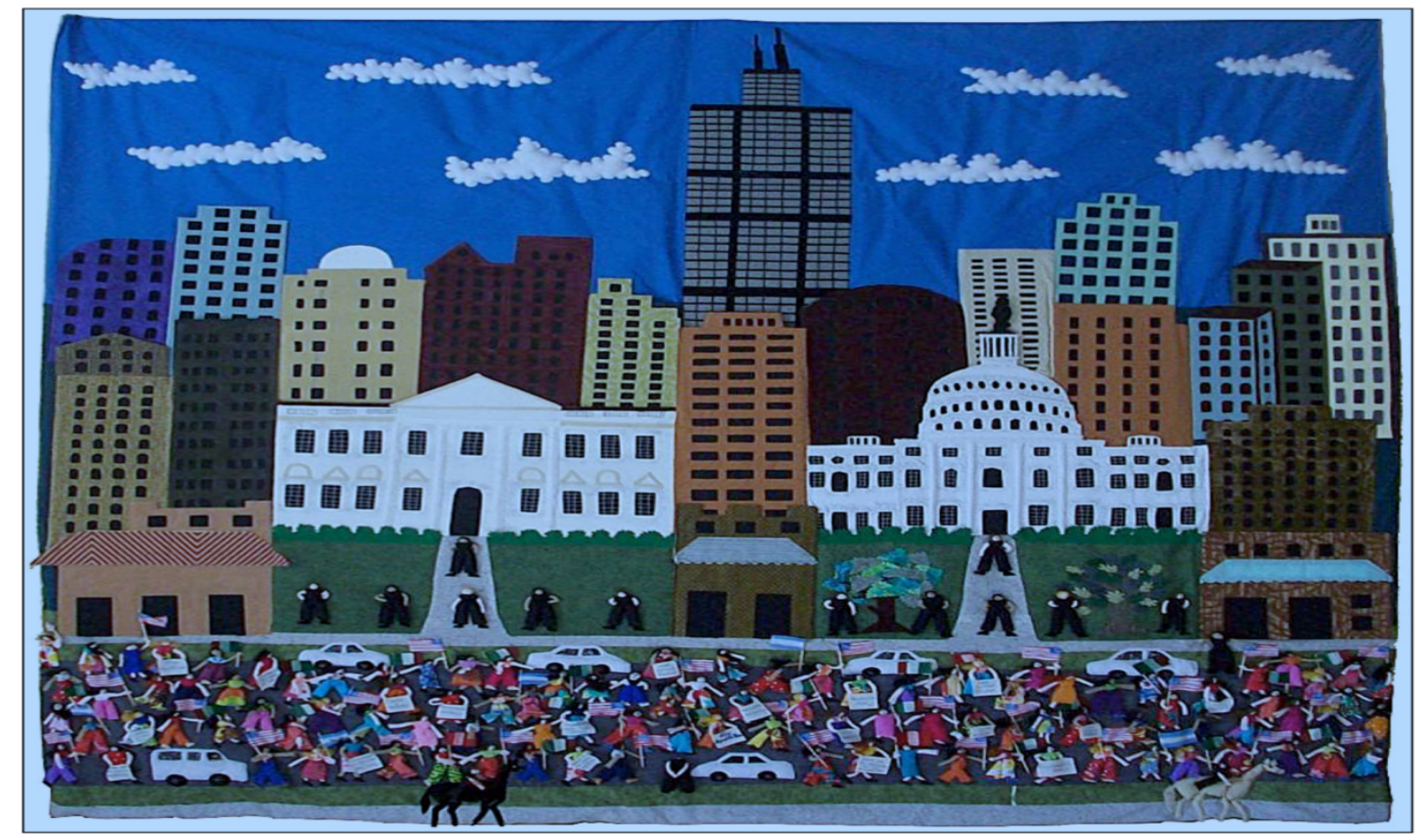

Görsel 4: "Gösteri”, Flora Zárate, (Zárate, F. (2012), Art and Politics: Contemporary Arpilleras, Textile Society of America Symposium Proceedings, Textile Society of America, 19-22 Eylül,

Bugün tehlikeli göç yollarında yaşamlarını kaybeden binlerce mülteci gibi Arpillera üreticisi kadınlar da iktidarın ölüme bırakma ve öldürme politikalarına maruz kalmışlardır. Onların mücadeleleri, bugünün beden politikalarının hapsettiği çerçevenin sınırları dahilinde yaşamları sahnelenen mülteciler için fikir açıcıdır. Mülteci bedeni, yaşam olarak kabul edilmeyen öteki bedenler gibi, belirli kodların içine sıkıştırıldıkça nesneleşir, insanlıktan çıkarılır. Bu ölüm siyasetinin mülteci bedenini hapsettiği çerçevenin kırılması için, doğrudan yaşam hakkı tanınmayan, yaşamları tehdit altında olanların perspektifinden temsil sahnesinin kurulduğu Arpillera gibi örneklere ihtiyaç vardır. Her biri ayrı ayrı kayıp yaşamış olan kadınlar, Arpillera üretimini kendi özgün yas tutma biçimlerine dönüştürürken, savaşlardan, şiddet olaylarından toplumların en fazla etkilenen kesimlerinin, kadınların yaşam mücadelesini görünür kılmış ve diri tutmuşlardır.

\footnotetext{
${ }^{5} \mathrm{Bu}$ çalışmada, farklı şehirlerde göçmenlerin yasallaştırılması için yapılan gösteriler anlatılmaktadır. Flora Zárate gibi bir çok sanatçı günümüzde de farklı boyutlarıyla toplumsal sorunları işlendiği Arpilleralar üretiyor. Bkz.

https://digitalcommons.unl.edu/cgi/viewcontent.cgi?article=1759\&context=tsaconf.
} 


\section{Sonuç Yerine}

Savaşlardan veya kötü koşullardan kaçarak daha güvenli bölgelerde yeniden yaşam kurmak zorunda bırakılan toplulukların yaşadıkları travmaların nasıl temsil edildiği sorusu, dikkatle ele alınması gereken bir mesele olarak önemini koruyor. Başta egemen medyanın ürettiği imgeler olmak üzere, mültecileri temsil eden görsel imgeler, onların yaşadıkları koşullara dair, kayıplarına dair bilgi vermekten ve farkındalık yaratmaktan uzaktır. Mültecilerin tehlikeli yolculuklarına odaklı ve grup kimliklerine işaret eden görselleştirmeler, onların yolculukları sırasında ve ulaştıkları yerlerde yaşadıkları insan hakları ihlalleri ve kayıplar hakkında düşünmeye sevk etmezler. Aksine, bir yanıyla mağdur, çaresiz, düşkün figürler sunarken öteki yanıyla, tekinsiz/tehlikeli kalabalıklar duygulanımını güçlendirirler. Mülteci bedenini kurban söylemiyle düşkünleştirirken, istenmeyen yabancılar imgesini pekiştirirler. Dolayısıyla, mülteci bedeninin tekrar eden temsilleri ile, bedene yönelik bio-politik ve nekro-politik stratejiler arasında güçlü bağlar vardır.

Mülteciler egemen medya temsilinde, dünyanın az gelişmiş coğrafyalarından gelen ve gelişmiş ülkelerin huzurunu bozacak, istila edecek kitleler olarak gösterildikçe hak talepleri görünmez hale gelmektedir. Temel insani intiyaçlar talebi, beden politikalarının yaşam hakkı tanıdığı alanlar dışında yok sayılmaktadır. Bu bağlamda, mevcut temsil biçimlerinde mülteci olanların kırılganlıkları işlenmemekte, aksine bu temsil biçimleri biz ve onlar ayrımına dayalı ön yargıları güçlendirebilmektedir. Görsel imgelerin toplumda yabancı düşmanlığını körükleyen, ayrımcılığı ve nefret söylemini besleyen araçlar olarak da ele alınması gerekmektedir. Sahip oldukları işlevlerin sorgulanması ve temsil biçimlerinin niteliğinin bu doğrultuda yeniden tartışmaya açılması gerekmektedir.

Şili'de kayıp yakınlarının yapmış oldukları Arpilleralar, tam da kaybın dilinin alışılmış formlarda kurulamadığı bir dönemde, duyulur olanın paylaşım sisteminde değişiklik yaratmıştır. Arpilleralar görsel imgelemde yeni bir duyumsama ve estetik deneyim alanı açmanın yollarından biri olarak karşımıza çıkmaktadır. Kaybı yaşayanların doğrudan kendi araçlarıyla, kendi dilleriyle kayıplarını aktardıkları bu örnek, onların üretimleri yoluyla mevcut toplumsal yapı içinde siyasal bir özne olarak konum talep etmeleri ve hakim görsel rejime muhalif bir alternatif sunmaları açısından oldukça önemlidir. Bu tür örneklerin temsil alanına sızması, özgün anlatıcılara yer 
açması, görsel imgeler aracılığıyla kaybın, acının ve yasın alternatif dilinin aranması imkanı yaratmaktadır. Arpilleraların bir varoluş mücadelesi olarak, bir direniş pratiği olarak görülmeleri mümkündür. Mevcut görme rejimini dönüştüremeyecek olsalar da yaşadığımız dünyada temsil etme ve edilme biçimlerinin yarattığı etkileri yeniden sorgulamamızın yollarından birini sunurlar. Bu makalede Arpilleralar, hakim görsel rejimi tartışmaya açma ve ona muhalefet etme potansiyeli nedeniyle, mültecilerin görsel imgesiyle birlikte ele alınmıştır. Mülteciler bugün hakim temsil alanında, muktedirlerin hatlarını çizdiği çerçeve içinde, yığınlar ya da kurbanlar olarak yer alsa da, bunun mutlak ve değişmez bir temsil biçimi olmadığını, temsil alanının bir mücadele alanı olduğunu kabul etmek önemlidir. Buradan hareketle mültecilerin aktif özneler olarak kendi deneyimlerini kendi araçlarıyla temsil etmelerinin önünü açacak yollar üzerine tartışmak gerekmektedir. 


\section{Kaynakça}

Adorno, Theodor (1999). "Geçmişin İşlenmesi Ne Demektir?" (Çev.) Tarhan Onur. Defter, 38: 121-137.

Adorno, Theodor (2011). Otoritaryen Kişilik Üstüne. (Çev.) Doğan Şahiner. İstanbul: Say.

Agamben, Giorgio (2001). Kutsal İnsan. (Çev.) İsmail Türkmen. İstanbul: Ayrıntı.

Ahmed, Sara (2014). Duyguların Kültürel Politikası. (Çev.) Sultan Komut. İstanbul: Sel. Azoulay, Ariella (2018a). "Fotoğrafın Eşitliği” Çev., Elçin Gen. E-scop. (26/11/2018) https://www.e-skop.com/skopbulten/fotografin-esitligi/4146, Erişim tarihi: 18 Eylül 2019.

Azoulay, Ariella (2018b). "Fotoğrafın Sahibi Kim: Başkalarını Fotoğraflama Hakkı" (Çev.) Derya Yılmaz. E-scop. (12/11/2018) https://www.eskop.com/skopbulten/fotografin-sahibi-kim-baskalarini-fotograflama-hakki/4086 Erişim tarihi: 20 Eylül 2019.

Azoulay, Ariella (2018c). "Insanların ve Nesnelerin Zorunlu Göçü” Çev., Derya Yılmaz. E-scop. 30/11/2018 https://www.e-skop.com/skopbulten/insanlarin-venesnelerin-zorunlu-gocu/4162 Erişim tarihi: 20 Eylül 2019

Bleiker, Roland, vd. (2013). "The Visual Dehumanisation of Refugees." Australian Journal of Political Sciences, 48: 398-416. DOI:10.1080/10361146.2013.840769. Erişim tarihi: 10.12.2019.

BM Mülteciler Yüksek Komiserliği Web Sayfası (2019). https://www.unhcr.org/tr/ Erişim tarihi: 21 Kasım 2019.

Butler, Judith (2005). Kırılgan Hayat. (Çev.) Başak Ertür. İstanbul: Metis.

Butler, Judith (2015). Savaş Tertipleri. (Çev.) Şeyda Öztürk. İstanbul: Yapı Kredi.

Caldwell, Dayna (2012). "The Chilean Arpilleristas: Changing National Politics Through Tapestry Work." Textile Society of America Symposium Proceedings. 665. Mildred Huie Museum. DigitalCommons@University of Nebraska. https://digitalcommons.unl.edu/cgi/viewcontent.cgi?article=1664. Erişim tarihi: 10 Kasım 2019.

Chouliaraki L, Stolic T (2017). "Rethinking Media Responsibility in the Refugee 'Crisis': A Visual Typology of European News". Media, Culture \& Society, 1-16. DOI: 10.1 77/0 1634 43717726163. Erişim tarihi: 24.12.2019. 
Foucault, Michel (2003). Cinselliğin Tarihi. (Çev.) Hülya Uğur Tanrı̈ver. İstanbul: Ayrıntı.

Foucault, Michel (2008). Toplumu Savunmak Gerekir. (Çev.) Şehsuvar Aktaş. İstanbul: Yapı Kredi.

Foucault, Michel (2016). Özne ve Iktidar. (Çev.) Osman Akınhay. İstanbul: Ayrıntı.

Freire, Danilo vd. (2017). "Deaths and Disappearances in the Pinochet Regime: A New

Dataset." Researchgate. https://www.researchgate.net/publication/320237272.

Erişim tarihi: 11 Kasım 2019.

Gambetti, Zeynep (2012). “Foucault'dan Agamben'e Olağanüstü Halin Sıradanlığına

Dair Bir Yanıt Denemesi." Cogito, 30: 70-71.

Google Yardım Kampanyası, https://www.campaigntr.com/googledan-multeci-vegocmen-krizi-icin-yardim-kampanyasi/ Erişim tarihi: 21.11.2019.

Göregenli, Melek (2013). "Temel Kavramlar: Önyargılar, Özcü İnançlar ve Ayrımcılık.” Medya ve Nefret Söylemi. Mahmut Çınar (der.) içinde. İstanbul: Hrant Dink Vakfı Yayınları. 23-39.

Hepimiz Göçmeniz Grubu Broşürü (2019). https://gocmeniz.org/broşür Erişim tarihi: 10 Aralık 2019.

Kaptanoğlu, Cem (2009). "Travma, Toplumsal Yas ve Bağışlama.” Toplum ve Hekim, 3(24): 212-215.

Malkki, Liisa H. (1997). "Speechless Emissaries: Refugees, Humanitarianism and Dehistoricization." In Siting Culture: The Shifting Anthropological Object. Karen Fog Olwig ve Kirsten Hastrup (der.) içinde. New York/London: Routledge.

Mbembe, Achille (2014). "Nekro-Siyaset” http://ayrintidergi.com.tr/nekro-siyaset/ Erişim tarihi: 12 Kasım 2019.

Morse, Tal (2016). "The Consturction of Grievable Death: Toward an Analytical Framework for the Study of Mediatized Death." European Journal of Cultural Studies, 1-17. DOI: 10.1177/1367549416656858. Erişim tarihi: 28.12.2019.

Özmakas, Utku (2018). Biyopolitika: İktidar ve Direniş. İstanbul: İletişim.

Oyman, Naile R (2019). "Tekstil Sanatlarında Sanat ve Politika İlişkisi Örneği: Umut ve Dayanışma Tekstilleri Arpilleralar." Uluslararası Sosyal Araştırmalar Dergisi, 12(68): 605-614. 
Ranciere, Jacques (2014). Estetiğin Huzursuzluğu. (Çev.) Aziz Ufuk Kılıç. İstanbul: İletişim.

Ranciere, Jacques (2015). Özgürleşen Seyirci. (Çev.) E. Burak Şaman. İstanbul: Metis.

Sontag, Susan (2004). Başkalarının Acısına Bakmak. (Çev.) O. Akınhay. İstanbul: Agora.

Taş, Tuğba (2017). "Ötekinin İmgesiyle Karşılaşma ve İzleyicinin Etik Sorumluluğu: Alan Kurdi İmgesi Üzerine Eleştirel Düşünceler.” Mülkiye Dergisi, 41(4): 3-28.

Toksoy, N. Gamze (2019). "Fotoğraf Aslında Neyin Belgesi? Fotoğrafın Toplumsallığı ve Medya ve Gerçeklik Tartışmalarında Değişmeyen Rolü." Mediterranean Journal of Humanities, IX(2): 491-505.

Türksam Göç Bülteni (2019). http://turksam.org/konu/goc-bulteni Erişim tarihi: 10 Aralık 2019

Zárate, Flora (2012). "Art and Politics: Contemporary Arpilleras, Textile Society of America Symposium Proceedings." Textile Society of America, 19-22 Eylül, 2012,

https://digitalcommons.unl.edu/cgi/viewcontent.cgi?article=1759\&context=tsaconf Erişim Tarihi: 10.11.2019. 